\title{
The Challenges of Corporate Social Responsibility Assessment Methodologies
}

\author{
Giannarakis Grigoris ${ }^{1}$
}

\begin{abstract}
:
Corporate Social Responsibility (CSR) has garnered significant interest for several years as Non-governmental organizations (NGOs), companies and scientific authors are involved in its promotion.

Numerous methodologies have been developed in order to assess the business CSR, affecting the stakeholders' attitude. The aim of this paper is to categorize the main challenges of ten methodologies that assess CSR. The selection of assessment methodologies was based on two criteria: their adoption by Social Responsible Investments Indexes (SRI indexes) and the assessment of multiple CSR dimensions.
\end{abstract}

The most comprehensive methodologies are those that are adopted by Dow Jones Sustainability Indexes, Ethibel Sustainability Index, KLD and Advanced Sustainable Performance Indices. Totally, nine assessment challenges are mentioned, some of which are: unspecific CSR criteria for each sector, unaccepted weight rate for each dimension or criterion, lack of transparency and ignorance of the main dimensions of society.

The value of this paper is to prompt the CSR methodologies to advance their procedure, taking into account the proposed challenges in order to assess social responsibility in a complete approach.

Key Words: Corporate Social Responsibility, Criteria, Assessment

\footnotetext{
${ }^{1}$ Technological Educational Institute of Western Macedonia, ggianaris@gmail.com
} 


\section{Introduction}

The Corporate Social Responsibility (CSR) has become a successful concept for companies in order to ensure their capacity for long term value and gain competitive advantages. It is an effective mean in order to mitigate the new type of risk that has emerged, known as social risk (Kytle and Ruggie, 2005). The authors and organizations describe the concept of CSR in different ways. The increased interest in the CSR measurement stems from the studies that suggest guidelines for developing CSR frameworks and mention the difficulties of CSR measurement (Mitchell, 1996; Jollands, 2006; Aravossis et al., 2006; Graafland et al., 2003; Graafland et al., 2004; Sachs et al., 2006; Kovačič, 2007; Turker, 2008; Carroll, 2000). There is no widely accepted methodology in order to assess and rank the company's social responsibility and no consensus exists regarding the criteria that should be measured and assessed. The authors take into consideration ten methodologies that assess CSR activities in order to expose the challenges that most of them face, giving examples where it is necessary.

The areas that are examined is the transparency provided by the assessment agencies, the proposal of specific criteria to specific sectors and countries, the agreement as regards the weight rate of the criteria, the suggestion of criteria that refer to the CSR outcome and irresponsibility, the assessment of the main stakeholders, the capability of criteria selection and the consensus of the CSR criteria. The value of this categorization is to take into account the main challenges of the proposed methodologies or the future ones in order to assess the social responsibility and rank or benchmark the companies in a complete approach. Moreover, it aims to contribute to the attempt for the assessment of the CSR performance in common terms.

For the purpose of this paper, the literature review of CSR is illustrated next, followed by a presentation of CSR performance measurement and methodologies in section 3. The major challenges of the proposed methodologies are described in section 4 and in the last part, section 5, the conclusion section is presented.

\section{Corporate Social Responsibility}

The CSR is a subjective concept and it has been characterized by lack of a universally agreed definition. Different approaches have been proposed in order to clarify the social responsibility concept. Freeman (1984) introduces the stakeholder theory in relation to social responsibilities of companies stating that the companies' responsibility is to "any group or individual who can affect or is affected by the achievement of the organization's objectives". Moreover, Carroll (1998) defines four different responsibilities in relation to the CSR: economic, legal, ethical, and discretionary/philanthropic. The World Business Council for Sustainable Development (1999) defines the CSR as the "...operating a business enterprise in a manner that consistently meets or exceeds the ethical, legal, commercial, and public 
expectations society has of business". Another definition proposed by the European Commission (2001) states that CSR “...means not only fulfilling legal expectations, but also going beyond compliance and investing 'more' into human capital, the environment and the relations with stakeholders", while Maignan and Farrell (2004) define it as the satisfaction of the stakeholders' demands. Dahlsrud (2006) investigated 37 definitions and found that the stakeholder and the social dimension appeared at $88 \%$, the economic dimension at $86 \%$, the voluntariness dimension appears at $80 \%$ and the environmental dimension at $59 \%$. The authors of this paper support that CSR actions belong to two categories: the first category refers to actions for decreasing the impact a company causes to external and internal stakeholders and the second one refers to actions that satisfy the society's expectations beyond the obligations of the law.

According to Haigh and Jones (2005), there are six main factors that drive companies to adopt CSR policy: intra-organizational factors, competitive dynamics, institutional investors, end-consumers, government regulators and non-governmental organizations. There are direct benefits companies look forward to, resulting from the implementation of CSR depending on the nature of the enterprise, however, Hopkins (2003) mentions that companies that adopt CSR should not expect benefits or rewards from the involvement in CSR. Next, there are some of the generic benefits that international literature refers:

- Improved financial performance (Schiebel and Pöchtrager, 2003; Business for Social Responsibility; Brown and Caylor, 2004);

- Increased ability to attract, motivate, and retain employees (Schiebel and Pöchtrager, 2003; Business for Social Responsibility; Crowther, 2002; Kotler and Lee, 2005; Epstein and Roy, 2001; Dutton and Dukerich, 1991; Greening and Turban, 2000);

- Reduced operating costs (Schiebel and Pöchtrager, 2003; Business for Social Responsibility; Crowther, 2002; Kotler and Lee, 2005; Azapagic, 2003; Christmann, 2000; Epstein and Roy, 2001; Klassen and Whybark, 1999; Marcus and Goodman, 1986);

- Enhanced Reputation (Schiebel and Pöchtrager, 2003; Business for Social Responsibility; Azapagic, 2003; Brown, 1998; Griffin and Mahon, 1997; Preston and O'Bannon, 1997; Epstein and Roy, 2001);

- Access to capital (Business for Social Responsibility; Epstein and Roy, 2001; Kotler and Lee, 2005; Azapagic, 2003).

There are cases of companies that increased their attention on CSR because of the public responses from the negative consequences of their business operations such as Nike, Shell Oil and Nestlee's bottled water (Porter and Kramer, 2006). During the last few years, a new stream of investigation appeared, that is the relationship between stock market and CSR (Dam, 2006; Ziegler et al., 2007), contrary to most 
of the researchers who try to investigate the behavior of stock market using macroeconomic indicators (Sariannidis et al., 2000; Drimbetas et al., 2007).

Generally, the concept of CSR means different things to different parties or stakeholders (Arlow and Gannon, 1982). Companies integrate social responsibility activities in their operations in a unique way (Palazzi and Starcher, 2001; Secchi, 2004; Gianakopoulou et al., 2016). It is important to mention that the stakeholders can "never fully understand a corporation's capabilities, competitive positioning, or the tradeoffs it must make" (Porter and Kramer, 2006), thus the stakeholders continuously demand from companies to be more responsible and devote more resources to them (McWilliams and Siegel, 2001). Some companies concentrated their CSR attention on multiple dimensions of society while others concentrated on a single dimension of society as their capability, economic or managerial, is limited or it is most important for them.

Additionally, Hopkins (2004) mentions that companies should be expected to involve in their operation the most significant stakeholder. In most of the cases, there is a common group of stakeholders (the most important) that companies are responsible for, beyond the law, a list which is extended and developed in relation to business strategy and needs.

\section{Corporate Social Responsibility Assessment Methodologies}

\subsection{Measurement of CSR performance}

The increased interest in CSR assessment is obvious from the plethora of proposed methodologies. The CSR actions cannot be measured by any single best approach (Wolfe and Aupperle, 1991). The concept of CSR is too broad and complex to include all the possible dimensions in a measurement framework.

Carroll (2000) mentions the importance of CSR measurement for the companies, insisting on a subjective measurement. Non - financial indicators greatly contribute to measurement of the CSR performance as the financial or traditional performance indicators have been criticized for their numerous limitations: not illustrate the exact interest of Stakeholders (Kaplan and Norton, 1996; Mbugua et al., 1999; Ho and Zhu, 2004), fail to measure and integrate all the essential factors of a business success (Eccles, 1991) and inflexibility to change (Richardson, 1980).

Igalens and Gond (2005) presented five best known Corporate Social Performance (CSP) models and mentioned that the measurement of CSR can be distinguished in five different categories: measurements based on analysis of the contents of annual reports, pollution indices, perceptual measurements derived from questionnaire based surveys, corporate reputation indicators and data produced by measurement organizations recognizing numerous limitations. They insisted that the ARESE data are reliable and appropriate for the measurement of CSP in French firms. Graafland et al. (2004) state the advantages that derive from CSR measurement and 
benchmarking. It serves transparency and accountability of the company's actions, cross company or internal comparison, simplicity of the judgement, systematic approach of the efforts, more objective view if the benchmarking is made by independent bodies and delivery of information from companies.

As regards the simplicity of judgement, the CSR index can be a source of information for various stakeholders in order to judge the CSR performance, affecting their attitude (Chatterji and Levine, 2006). Consumers could change their decisions in relation to the CSR (MORI, 2003; Mitchell, 2001; Sen and Bhattacharya, 2001; Vogel, 2005) and investors identify companies that meet high CSR standards in order to invest as there is a positive relationship between the CSR and corporate financial performance (Waddock and Graves, 1997; Frooman, 1997; Griffin and Mahon, 1997; Margolis and Walsh, 2001).

An important topic of the CSR assessment procedure is the measurement of the CSR performance and numerous authors mention its importance and benefits. A reason as regard the importance of performance measurement is given by Harrington (1987), "if you can't measure something, you can't understand it; if you can't understand it, you can't control it; if you can't control it, you can't improve it". Brown (1996) supports that the performance measurement shows if the organizations achieve their goals or not. According to Simmons (2000), performance measurement helps companies to set business goals periodically (both in short or long term) and provides managers with valuable information towards the progress of goals.

Additionally, Bititci et al. (2002) state five reasons on the necessity of measuring performance: monitor and control, drive improvement, maximize the effectiveness of the improvement effort; achieve alignment with organizational goals and objectives, reward and discipline.

\subsection{Sample of Corporate social Responsibility methodologies}

The selection of the methodologies that are taken into account was based on the following two criteria: Firstly, the assessment methodologies are adopted by SRI Indexes. Secondly, the assessment of multiple dimensions of CSR and not only one dimension as Greendex, which measures and monitors consumer's progress towards environmentally sustainable consumption in 14 countries, or Environmental Sustainability Index or Corporate Equality Index. Although SRI have been realized for the last 100 years, the SRI indexes were introduced the last years (Fowler and Hope, 2007), namely the oldest SRI indexed Domini 400 Social Index dates back from 1990. Totally, ten assessment methodologies were identified that satisfy the above criteria which most of them are realized by independent organizations, agencies and companies, Table 1.

Table 1. A list of CSR assessment methodologies that are adopted from different SRI indexes 


\begin{tabular}{|l|l|}
\hline 1 & Dow Jones Sustainability Indexes (DJSI) \\
\hline 2 & Ethibel Sustainability Index (ESI) \\
\hline 3 & Calvert Social Index \\
\hline 4 & FTSE4Good Index \\
\hline 5 & KLD - Domini 400 Social Index \\
\hline 6 & Advanced Sustainable Performance Indices (ASPI) \\
\hline 7 & JSE SRI Index \\
\hline 8 & Maala Index \\
\hline 9 & Jantzi Social Index \\
\hline 10 & OWW Consulting-Malaysia \\
\hline
\end{tabular}

Different methodological procedures exist in order to assess a company's CSR; however, efforts were made to detect similarities as regards the procedure of all methodologies:

- evaluation of predetermined group of companies;

- support on reliable sources of information: internal, such as companies' reports and questionnaires and external, such as press, media and databases;

- suggestion of their own criteria that are relative to CSR, Triple Bottom Line or Corporate Sustainability concept;

- re-evaluation of companies' performance in predetermined periods.

As regards the evaluation of pre-determined group companies, the DJSI derives from and is fully integrated with the Dow Jones Global Indexes while the ESI and the FTSE4Good cover Global stock indexes. The KLD assesses primarily large-cap U.S. stock companies while the Calvert Social Index represents companies which belong to NYSE, NASDAQ and AMEX, U.S - based companies.

The ASPI index encompasses the 120 best companies of the DJ EURO STOXX, the Maala Index rates the largest public and private companies in Israel and companies in the Tel Aviv 100 Index or companies with an annual profit greater than $\$ 100$ million, while the OWW Consulting-Malaysia methodology evaluates companies that operate in Malaysia. The Jantzi Research Inc assesses the performance rate of approximately 60 Canadian companies covering the Canadian market, and the JSE SRI Index includes companies from FTSE/JSE Africa Index.

The question that emerges is which assessment methodology should be selected by companies in order to assess their CSR if they do not satisfy the aforementioned requirements. It is obvious that the small and medium companies cannot be assessed as all of the aforementioned methodologies referred to companies listed in a stock market. The authors regard this limitation as a characteristic of the methodologies, even though this could be considered a "challenge".

Concerning the reevaluation process of companies' performance, the ASPI methodology is reviewed annually and quarterly. In ESI methodology, a quick 
updating takes place annually and complete reevaluation after three years, while in Calvert Index methodology, there is an annual reconstitution. The methodologies of KLD, DJSI and JSE SRI Index are reviewed annually while FTSE4Good indices are reviewed semiannually.

The assessment methodologies are widely accepted by different stakeholders, consequently, the CSR can be used as a marketing tool from companies in order to build their image (L'Etang, 1996) or as a tool for stakeholders' communication (Azapagic and Perdan, 2000; Institution of Chemical Engineers, 2002). This is the case, because companies are concerned with improving the CSR reputation as it can be more valuable and important than the actual CSR because the stakeholder loyalty affects them financially (Brown, 1998). The majority of the aforementioned CSR methodologies emerged in response to the increased interest of investors in companies that have integrated CSR standards in their corporations (Greene, 2003).

\section{Challenges of CSR Assessment Methodologies}

In the literature review, authors concentrate their efforts more on specific challenges for each of the proposed CSR assessment methodologies and less on general common challenges (Entine, 2003; Porter and Kramer, 2006; Chatterji and Levine, 2006; Schwab, 2005; Fowler and Hope, 2007; Průša, 2007). Next, there is an attempt to categorize the main challenges that are presented in the CSR assessment methodologies, giving examples where it is necessary.

\subsection{Lack of transparency}

The assessment agencies do not publish details concerning important aspects of their methodology. They do not exactly provide the criteria that they take into consideration in order to calculate the CSR score, presenting general directions as OWW Consulting-Malaysia, KLD (Domini 400 Social Index), Calvert Social Index, FTSE4Good and ASPI do. The DJSI even if publish the general criteria for the assessment of CSR, however, it does not publish the specific criteria for each sector, while Jantzi Social Index provides only a sample report with the CSR criteria.

Additionally, the proposed methodologies do not accurately report the rating weight for each criterion - category and/or do not publish the CSR methodology calculation score. The agencies do not mention how the methodologies treat external and internal sources of information, except the questionnaire, in the CSR score procedure. The methodological information that is not published possibly constitutes a piece of asset information for companies or agencies that support the methodologies.

However, this dimness does not allow each interested stakeholder to be precisely informed about the methodology that each assessment agency adopts. Transparency for companies is considered a very important asset as it can ensure competitive advantages. The CSR assessment agencies support that using their methodology a 
transparency of the companies' actions is achieved but in practice, the same agencies do not illustrate transparency in their methodological steps. The lack of transparency is considered the most important challenge affecting their categorization process.

\subsection{Proposed general criteria}

In the international literature, there are two trends concerning the kind of the criteria for the assessment of the CSR. The first involves the introduction of general criteria while the second suggests both general and specific criteria.

The first identifies general criteria that are applicable to all types of companies or sectors. Including only these types of criteria does not take into account specific actions that integrate the business in their operations, as each sector is distinguished by special challenges and trends.

The second trend involves both general and specific criteria which importance is provided by Secchi model in order to classify the commitment of the CSR. The sector dimension is one of the three elements of the proposed model (Secchi, 2004), even though Morimoto et al. (2004) state that it is difficult to include criteria in a CSR framework that are applicable to all types of sectors.

There are many authors or institutions that concentrate their efforts on specific sectors such as Lambrou (2006), Fafaliou et al. (2002) in Greek Shipping, Sachs et al. (2006) and Mudzamir and Norfaiezah (2007) in telecommunications, Global Reporting Initiative (GRI), proposing indicators for seven different sectors and Azapagic (2003), recommending indicators for the mining and mineral industry. Similarly, ESI mentions that the company's performance depends on the sector and region where the company operates.

Griffin and Mahon (1997) claimed that each sector faces different social pressures, criticizing the cross-sectional analysis. Unique exception is the methodology of DJSI which contains both general and specific criteria for each of the 58 sectors, separately. Although, there are numerous references for the need of adoption of both general and specific criteria, the agencies suggest general criteria, probably because they believe that the assessment should be made by only one type of criteria.

\subsection{Not accepted weight rate of criteria}

Examining the methodologies, it can be observed that there is no acceptable weight rate for each dimension of stakeholder or criterion (DJSI, ESI, Maala Index and KLD). The assessment agencies rate by using high weight criteria or categories that are more important to the society than others. The methodologies of ESI, KLD and Maala Index provide the same weight rate for each dimension of stakeholders or aspects of society. Additionally, the JSE SRI Index, OWW Consulting-Malaysia and FTSE4Good include an environmental classification according to companies' impact in order to differentiate the weight rate of the environmental criteria. The OWW Consulting-Malaysia weights the criteria according to specific concerns of the 
Malaysian stakeholders. The weight rate has changed during the years, for example, the DJSI weights the general criteria with $60 \%$ and the specific criteria with $40 \%$ before 2006, but this percentage changed in 2006 and both types of criteria are equal.

Each sector has specific characteristics and consequently, each dimension has different importance and different weight rate, for example, industries and services have different effects on the environment. The weight in CSR methodologies seems arbitrary and the concept of the origin should be explained (Chatterji and Levine, 2006). It should be taken into account by the CSR agencies whether the weight rate of criteria could be differentiated depending on the sector where the company belongs.

\subsection{Lack of consensus criteria and invalid criteria}

Lack of consensus exists as regards which categories or criteria should be measured, as Porter and Kramer (2006) agree, since the concept of the CSR is not accurate yet. Even though there are many similar dimensions there are numerous proposed criteria. Hamner (2006) investigated twelve CSR assessment methodologies, distinguished 202 criteria and found that the dimension of health and safety appeared at $75 \%$, the dimension of corporate governance, CSR performance reporting, labor and union relations and pollution prevention at $67 \%$ and innovation, benefits and human rights at $42 \%$ rendering the categorization a difficult and complex procedure.

Each methodology tends to measure criteria that are appropriate to agencies' perception; consequently the categorization procedure remains complex. There are methodologies that suggest numerous criteria of the CSR, as Jantzi Social Index proposes more than 200, so the main criteria do not receive the required importance.

Additionally, the assessment agencies tend to include in their methodology every action of the companies which most of the times are easily feasible and/or invalid, measuring partially the CSR performance, such as: the number of women that are members of the company's board of directors/supervisory board (DJSI, KLD and Jantzi Social Index), the number of short-term contracts (ESI) and the total number of employees (Jantzi Social Index). A result of the invalid criteria is that enterprises can increase CSR score even if they do not fulfil significant criteria. Carroll (2000) expresses doubts about the validity and reliability of the measures that could be developed.

\subsection{Limited criteria relative to the outcome}

The CSR assessment agencies do not include in their methodology adequate criteria that refer to the outcome of their CSR activities. The importance of the CSR outcome is mentioned by Brown (1998), Porter and Kramer (2006), Wartick and Cochran (1985), Wood (1991) and Moran (2008) contrary to Graafland et al. (2004) who support that "if the intention of a moral action is good, the action itself is morally good. The outcome of that action does not matter". Most of the 
methodologies propose guideline criteria as regards the CSR assessment without concentrating their efforts on assessing the outcome of the CSR activities. They appear more as marketing tool rather than as an assessment tool.

The proportion of outcome criteria with the total number of criteria is negligible. Vogel (2005) mentions that companies should monitor the consequences of their actions for example, restrictions for the child labor can lead children to a more dangerous working environment, like prostitution. It is obvious that the procedure of criteria introduction in relation to the outcome should be made with great attention and be adapted to the environment that companies operate. However, it should be stated that the outcome of CSR activities does not totally depend on the companies, as CSR achievements are affected by a complex business environment.

\subsection{Non correspondence to characteristics of each Country}

There are two different approaches that assess the CSR in connection with the characteristics of each country. The first approach claims that each country or market has specific characteristics that distinguish it from others. Some of the methodologies that assess the CSR score take into consideration these specific characteristics in their calculation model. Secchi (2004) proposed that the CSR should be assessed in the field of each country because each one has different legal and political constraints, economic structure and cultural and social variables. The JSE SRI Index includes criteria such as demonstration of objectives relating to employees' health and safety, including HIV/AIDS.

However, there is a different procedure for multinational companies. The SRI Index of OWW Consulting-Malaysia in the dimension of Marketplace includes criteria that are related with Islamic Financing. Maala index takes into account both international and local standards relative to Israel market. Moreover, there are criteria adapted absolutely to the requirements of religions as Dow Jones Islamic Market Sustainability Index that presents companies that are socially responsible and compatible with Islamic investment guidelines or KLD Catholic Values 400 Index available to Catholic investors. Such examples of criteria do not have the same value or importance for the companies of other countries as in Greece.

According to D'Arcimoles and Trebucq (2002) Corporate Social Performance and Stakeholders can change from one country to another because of cultural or methodological differences. The second approach supports that there are indexes which do not take into account the specific conditions of the countries or the markets that examine. The Sam group proposes two indexes, the DJSI and Australian SAM sustainability index. Both include the same criteria even if they examine the CSR activities in different markets or countries. Other examples are the methodologies of ESI and FTSE4Good. Even if many CSR assessment methodologies that adopt special characteristics exist, it is obvious that the companies that do not operate in countries or markets with specific characteristics as the above should be assessed in general terms. 


\subsection{Inadequate assessment of the main CSR dimensions}

Most definitions of CSR referred to the satisfaction of a stakeholder or generally to the society. The agencies that are specialized in the assessment of the CSR do not take into consideration certain stakeholders/aspects of society or refer to them in limited extend. It is important for the methodologies to include all the dimensions or stakeholders of society because each of them has different concerns. Typical examples of the stakeholders or the aspects of society that are not taken into consideration by the CSR score calculation are:

- The majority of proposed methodologies do not pay the required attention to suppliers, even if considered one of the major stakeholders. Unique exception is the methodology proposed by Domini 400 Social Index;

- Calvert Social Index does not contain economic criteria in its assessment process;

- DJSI family indexes do not support criteria regarding product safety and social impact;

- JSE SRI Index does not support adequate criteria as regards customers;

- KLD (Domini 400 Social Index) does not give the appropriate attention to corporate governance and to social reporting of companies;

- FTSE4Good does not contain criteria relevant to economic, customer services, corporate governance;

- ESI does not count actions relevant to corporate governance, health and safety of workers and employee participation on the final score. Similar challenges confront the Maala Index.

Generally, most of the companies satisfy the expectations of a core list of stakeholders, which can be developed or limited, according to their business strategy and needs. It is difficult to answer why the CSR assessment agencies do not include major stakeholders that are important to all type of companies as suppliers or employees.

\subsection{Limitations of criteria of corporate social irresponsibility}

Strike et al. (2006) define the Corporate Social Irresponsibility as "the set of corporate actions that negatively affects an identifiable social stakeholder's legitimate claims (in the long run)". The importance of positive and negative indicators is mentioned by Krajnc and Glavič (2005) proposing that a CSR framework should include both positive and negative criteria. Every attempt for the assessment of the CSR should consider the Kotchen and Moon (2007) conclusions that "when companies do more harm, they also do more good" taking into consideration approximately 3.000 traded companies.

Most of the CSR agencies introduce, more or less, the same criteria as regards the negative consequences and only in certain dimensions of Stakeholders, such as the 
environment pollution, neglecting other stakeholders as employees. The agencies hesitate to introduce criteria in order to assess negative consequences. It is important for the CSR assessment to contain dimensions of social irresponsibility as the satisfaction of stakeholder beyond the law is not beneficial if companies do not obey the law. Unique exception is the methodology proposed by Jantzi Social Index.

\subsection{Selection of the criteria of the CSR assessment}

The methodologies of FTSE4Good, OWW Consulting-Malaysia and JSE SRI INDEX classify each sector according to their direct and/or indirect impact on the environment, for example, the JSE SRI INDEX adopts the EIRIS' environmental classification. Companies have the opportunity to select in accordance with the category they belong to, the criteria they wish or want to fulfill in order to be assessed by the agencies. Companies have the opportunity to select which criteria of the environment will be responsible for, ignoring the rest.

Furthermore, they may act irresponsibly to criteria that they neglect. A CSR assessment methodology should avoid giving the choice to companies to select the areas to be responsible for, as happens to the remaining methodologies in which the CSR criteria are obligatory.

\section{Discussion and Conclusion}

The authors' interest was triggered by the fact that no previous studies exist regarding the general challenges of the CSR methodologies. The increased number of the CSR methodologies that exist show the necessity for the assessment of the CSR performance.

The methodologies that evaluate companies in terms of CSR standards are not similar. The assessment of the CSR is a new topic in the business field and little improvements or changes are introduced each time that a new assessment methodology appears. The authors try to identify the main challenges of the CSR assessment, giving examples from the proposed methodologies. Ten different methodologies have been selected so as to categorize the main challenges that they face.

The challenges mentioned in the paper could be motives for further improvement. Nine challenges are identified, the most important of which are: lack of transparency, proposal of general criteria, neglection of the main business stakeholder and not introduction of criteria relative to the CSR outcome. Giving attention to the above challenges, a more complete assessment methodology can be made.

Proposed actions are made for CSR methodology improvements: firstly, more efforts should be made from the agencies that assess the CSR to provide more information about their methodologies in order to be more transparent, for example, what 
specific criteria are adopted or how CSR scores are estimated. Additionally, further discussion is needed among scientific and business community and other bodies in order to define exactly the concept of CSR and its dimensions where the role of businesses in this dialogue is vital as they adopt, implement and develop CSR activities. In response to specific characteristics of each sector and country, where companies operate, more specific criteria need to be introduced in CSR assessment methodologies provided by the relevant literature. It is mandatory for the business community to reconsider the introduction of the criteria with reference to the outcome of the CSR in order to verify the degree of its success.

\section{References}

Advanced Sustainable Performance Indices, available at: www.vigeo.com

Aravossis, K., Panayiotou, A. and Tsousi, K. (2006), “A Proposed Methodological

Framework for the Evaluation of Corporate Social Responsibility", proceedings of the 1st International Conference on Environmental Economics and Investment Assessment, Mykonos, Greece.

Arlow, P. and Gannon, M.J. (1982), "Social Responsiveness, Corporate Structure and Economic Performance", Academy of Management Review, Vol. 7, pp. 235-241.

Azapagic, A. and Perdan, S. (2000), "Indicators of sustainable development for industry: A general framework", Transactions of the Institution of Chemical Engineers, Vol. 78(B4), pp. 243-61.

Azapagic, A. (2003), "Systems approach to corporate sustainability: A general management framework, Process Safety \& Environmental Protection”, Transactions of the Institution of Chemical Engineers, Vol. 81, pp. 303-316.

Bititci, U., Carrie, A. and Turner, T. (2002), "Integrated performance measurement systems: Structure and dynamics", in, Neely, A. (ed.) Business performance measurement. Theory and practice, Cambridge, Cambridge University Press.

Brown, D.L. and Caylor, M.L. (2004), "Corporate Governance Study: The Correlation between Corporate Governance and Company Performance", Corporate Governance Study, Institutional Shareholder Services.

Brown, M.G. (1996), Keeping score: using the right metrics to drive world - class performance, Pup. Portland: U.S.A.

Business for Social Responsibility, available at: www.bsr.org

Calvert Social Index, available at: www.calvert.com

Carroll, A.B. (1998), "The Four Faces of Corporate Citizenship", Business and Society Review, Vol. 100, pp. 1-7.

Carroll, A.B. (2000), "A Commentary and an Overview of Key Questions on Corporate Social Performance Measurement”, Business and Society, Vol. 39, pp. 466-78.

Chatterji, A. and Levine, D. (2006), "Breaking Down The Wall Of Codes: Evaluating NonFinancial Performance Measurement", California Management Review, Vol. 48, pp. 29-51.

Christmann, P. (2000), "Effects of "best practices" of environmental management on cost advantage: the role of complementary assets|", Academy of Management Journal, Vol. 43, pp. 663-80.

Corporate Equality Index, available at: http://www.hrc.org/issues/workplace/cei.htm Crowther, D. (2002), A Social Critique of Corporate Reporting, Aldershot, Ashgate, UK.

Dahlsrud, A. (2006), "How Corporate Social Responsibility is Defined: an Analysis of 37 
Definitions", Corporate Social Responsibility and Environmental Management, Vol. 15, pp. 1-13.

Dam, L. (2006), "Corporate social responsibility in a general equilibrium stock market model: Solving the financial performance puzzle", CCSO Working Papers, CCSO Centre for Economic Research, available at: http://ccso.eldoc.ub.rug.nl/FILES/root/2006/200603/200603.pdf

D'Arcimoles, C.H. and Trebucq, S. (2002), "The Corporate Social Performance-Financial Performance Link: Evidence from France", University of Bordeaux Department of International Accounting Working Paper No. 02-01., available at SSRN: $\mathrm{http} / / / \mathrm{ssrn} . \mathrm{com} / \mathrm{abstract}=306599$ or DOI: $10.2139 / \mathrm{ssrn} .306599$

Dow Jones Sustainability Indexes, available at: www.sustainability-index.com

Drimbetas, E., Sariannidis, N. and Porfiris, N. (2007), "The Effect of Derivatives Trading on Volatility of the Underlying Asset: Evidence from the Greek Stock Market”, Applied Financial Economics, Vol. 17, pp. 139-148.

Dutton, J.E. and Dukerich, J.M. (1991), "Keeping an eye on the mirror: image and identity in organizational adaption", Academy of Management Journal, Vol. 34, pp. 517-54.

Eccles, R.G. (1991), “The performance measurement manifesto", Harvard Business Review, January/February, pp. 617-35.

Entine, J. (2003), "The myth of social investing. A Critique of Its Practice and Consequences for Corporate Social Performance Research", Organization and Environment, Vol. 16, pp. 352-68.

Environmental Sustainability Index (2002), 2001 Environmental Sustainability Index, Yale Center for Environmental Law \& Policy, New Haven.

Epstein, M.J. and Roy, M.J. (2001), "Sustainability in action: Identifying and measuring the key performance drivers", Long Range Planning, Vol. 34, pp. 585-604.

Ethibel Sustainability Index, available at: www.ethibel.org

European Commission (2001) Green Paper: Promoting a European framework for Corporate Social Responsibility, Brussels.

Fafaliou, I., Lekakou, M. and Theotokas, J. (2006), "Is the European shipping industry aware of corporate social responsibility? The case of the Greek-owned short sea shipping companies", Marine Policy, Vol. 30, pp. 412-419.

Fowler, S.J. and Hope, C. (2007), “A Critical Review of Sustainable Business Indices and their Impact”, Journal of Business Ethics, Vol. 76, pp. 243-252.

Freeman, R.E. (1984), Strategic Management: A Stakeholder Approach, Pitman, Boston, MA.

Frooman, J. (1997), "Socially irresponsible and illegal behavior and shareholder wealth: A meta-analysis of event studies", Business and Society, Vol. 36, pp. 221-49.

FTSE4Good Index, available at: www.ftse.com/Indices/FTSE4Good_Index_Series/index.jsp Global Reporting Initiative (GRI), available at:

http://www.globalreporting.org/ReportingFramework/G3Online/SectorSupplements

Gianakopoulou N.E., Stamatopoulos V.T. and Thalassinos I.E. (2016), „Corporate governance in shipping: an overview", Maritime Policy and Management, Vol. 43(1), 19-38.

Graafland, J.J., Eijffinger, S.C.W. and Smid, H. (2004), "Benchmarking of Corporate Social Responsibility: Methodological Problems and Robustness", Journal of Business Ethics, Vol. 53, pp. 137-52.

Graafland, J.J., Eijffinger, S.C.W., Stoffele, N.C.G.M., Smid, H. and Coldeweijer, A.M. (2003), "Corporate social responsibility of Dutch companies: Benchmarking and Transparency”, available at: http://www.uvt.nl/faculteiten/fww/cmo 
Greendex, available at: http://event.nationalgeographic.com/greendex

Greene, D. (2003), Socially Responsible Investment in Australia, Ethical Investment Association, Sydney.

Greening, D. and Turban, D. (2000), "Corporate social performance as a competitive advantage in attracting a quality work force", Business and Society, Vol. 39, pp. 254-80.

Griffin, J.J. and Mahon, J.F. (1997), "The corporate social performance and corporate financial performance debate: Twenty-five years of incomparable research", Business and Society, Vol. 36, pp. 5-31.

Haigh, M. and Jones, M.T. (2005), "The drivers of corporate social responsibility: a critical review", in, Economic Forum on Global Business and Economics Research, Istanbul, 2005. Ashridge, UK, Ashridge Business School, available at: http://www.ashridge.org.uk/Website/IC.nsf/wFARATT/The\%20Drivers\%20of\%20 Corporate\%20Social\%20Responsbilility:\%20A\%20critcial\%20review/\$file/TheDri versOfCorporateSocialResponsibilityACriticalReview.pdf

Hamner, B. (2006), "Integrating Market-Based Sustainability Indicators and Performance Management Systems", Working paper, Hamner and Associates LLC.

Harrington, H.J. (1987), The Improvement Process, McGraw-Hill, New York, NY, p. 103.

Ho, C.T. and Zhu, D.S. (2004), "Performance measurement of Taiwan's commercial banks", International Journal of Productivity and Performance Management, Vol. 53, pp. 425-34.

Hopkins, M. (2003), The Planetary Bargain, Earthscan, UK.

Hopkins, M. (2004), "Corporate social responsibility: an issues paper", Working Paper No. 27, Policy Integration Department World Commission on the Social Dimension of Globalization International Labour Office Geneva.

Igalens, J. and Gond, J.P. (2005), "Measuring Corporate Social Performance in France: A Critical and Empirical Analysis of ARESE data", Journal of Business Ethics, Vol. 56, pp. 131-148.

Institution of Chemical Engineers, (2002), Sustainability metrics. Rugby: The Institution of Chemical Engineers, IChemE: Rugby, UK.

Jantzi Social Index (JSI), available at: www.jantzisocialindex.com

Jollands, N. (2006), "How to aggregate sustainable development indicators: a proposed framework and its application", International Journal of Agricultural Resources, Governance and Ecology, Vol. 5, pp. 18-34.

JSE SRI Index, available at: http://www.jse.co.za/sri/introduction.jsp

Kaplan, R.S. and Norton, D.P. (1996), The Balanced Scorecard: Translating Strategy into Action, Harvard Business School Press, Boston.

Klassen, R.D. and Whybark, D.C. (1999), "The impact of environmental technologies on manufacturing performance", Academy of Management Journal, Vol. 42, pp. 599615.

KLD, available at: http://www.kld.com

Kotchen, M.J. and Moon, J.J. (2007), "Corporate Social Responsibility for Irresponsibility", WORKING PAPER, hosted by UCLA School of Public Affairs (SPA) Environmental Cluster Series.

Kotler, P. and Lee, N. (2005), Corporate Social Responsibility. Doing the Most Good for Your Company and Your Cause, John Wiley \& Sons, Inc., Hoboken, NJ.

Kovačič, A. (2007), "Sustainable Development and the Problems of Measuring", International Journal of Humanities and Social Sciences, Vol. 1, No. 2.

Krajnc, D. and Glavič, P. (2005), “A model for integrated assessment of sustainable 
development", Resources, Conservation and Recycling, Vol. 43, pp. 189-208.

Kytle, B. and Ruggie, J.G. (2005), "Corporate Social Responsibility as Risk Management: A Model for Multinationals", Corporate Social Responsibility Initiative Working paper No. 10. Cambridge, MA: John F. Kennedy School of Government, Harvard University.

Lambrou, M. (2006), "Reflections on digital CSR-aware shipping", International Conference - Shipping in the era of Social Responsibility, Argostoli, Cephalonia, Greece.

L'Etang, J. (1996), "Corporate responsibility and public relations ethics", Critical Perspectives in Public Relations, pp 82-105.

Maala Index, available at: http://www.maala.org.il/eng/tools/index/01/default.asp?ContentID=338

Maignan, I. and Farrell, O.C. (2004), "Corporate Social Responsibility and Marketing: An Integrative Framework", Journal of the Academy of Marketing Science, Vol. 32, pp. 3-19.

Marcus, A.A. and Goodman, R.S. (1986), "Compliance and performance: toward a contingency theory research", in Preston, L.E. (Ed.), Corporate Social Performance and Policy, JAI Press, Greenwich, CT, pp. 193-221.

Margolis, J.D. and Walsh, J.P. (2001), People and Profits: The Search for a Link between a Company's Social and Financial Performance, Erlbaum, Mahwah, N.J.

Mbugua, L., Harris, P.T., Holt, G.D. and Olomolaiye, P.O. (1999), “A framework for determining critical success factors influencing construction business performance", proceedings of the Association of Researchers in Construction Management 15th Annual Conference, Vol. 1, Liverpool John Moores University, Liverpool, 15-17 September, pp. 255-64.

McWilliams, A. and Siegel D. (2001), "Corporate Social Responsibility: A theory of the firm perspective", Academy of Management Review, Vol. 26, pp. 117-27.

Mitchell, A. (2001), Right Side Up, Harper Collins Business, London.

Mitchell, G. (1996), "Problems and fundamentals of sustainable development indicators", Sustainable Development, Vol. 4, pp. 1-11

MORI, (2003), "The Public's Views of Corporate Responsibility 2003”, available at: http://www.ipsos-mori.com/publications/jld/publics-views-of-corporateresponsibilty.pdf

Morimoto, R., Ash, J. and Hope, C. (2004), “Corporate Social Responsibility Audit: From Theory to Practice", University of Cambridge, Judge Institute of Management Working Paper No. 14/2004, available at SSRN: http://ssrn.com/abstract=670144 or DOI: HYPERLINK "http://dx.doi.org/10.2139/ssrn.670144"10.2139/ssrn.670144.

Mudzamir, B.M. and Norfaiezah, B.S. (2007), "Corporate Social Responsibility (CSR) activities in Mobile Telecommunication industry: case study of Malaysia", European Critical Accounting Conference, available at: http://www.standrews.ac.uk/management/ecas/7/

OWW Consulting-Malaysia, available at: www.oww-consulting.com

Palazzi, M. and Starcher, G. (2000), "Corporate Social Responsibility and Business Success", paper found in the web-site: http://www.ebbf.org

Porter, M.E. and. Kramer, M.R. (2006), "Strategy and Society - The Link Between Competitive Advantage and Corporate Social Responsibility", Harvard Business Review, HBR Spotlight.

Preston, L.E. and O'Bannon, D.P. (1997), “The corporate social-financial performance relationship: a typology and analysis", Business and Society, Vol. 36, pp. 419-29.

Průša, P. (2007), "How Can Corporate Social Responsibility Be Assessed?", Faculty of 
International Relations Working Papers, available at: http://vz.fmv.vse.cz/wpcontent/uploads/9_2007.pdf

Richardson, P.R. and Gordon, J.M.R. (1980), "Measuring total manufacturing performance measures have to agree?", Management Accounting, Vol. 72, pp. 28-36.

Sachs, S., Maurer, M., Ruhli, E. and Hoffmann, R. (2006), "Corporate social responsibility from a "stakeholder view" perspective: CSR implementation by a Swiss mobile telecommunication provider", Corporate Governance, Vol. 6, pp. 506-15.

Sariannidis, N., Drimbetas, E. and Konteos, G. (2006), "Impact of International Volatility, the Euro, and Derivatives on a Small Stock Market", International Review of Applied Economic Research, Vol. 1, pp. 1-22.

Schiebel, W. and Pöchtrager, S. (2003), "Corporate ethics as a factor for success - the measurement instrument of the University of Agricultural Sciences (BOKU), Vienna”, Supply Chain Management: An International Journal, Vol. 8, pp. 116-121.

Schwab, D. (2005), “The Sustainable Investment Opportunity in Israel”, available at: http://www.socialaction.com/SRI_in_Israel.pdf

Secchi, D. (2004), "Corporate Social Responsibility in Europe: Analyzing Business in Transnational Contexts”, Università degli Studi dell'Insubria, available at: http://eco.uninsubria.it

Sen, S. and Bhattacharya, C.B. (2001), "Does Doing Good Always Lead to Doing Better? Consumer Reactions to Corporate Social Responsibility", Journal of Marketing Research, Vol. 38, pp. 225-43.

Simmons, R. (2000), Performance Measurement and Control Systems for Implementing Strategy, Prentice Hall.

Strike, V.M., Gao, J. and Bansal, P. (2006), "Being good while being bad: social responsibility and the international diversification of US firms", Journal of International Business Studies, Vol. 37, pp. 850-62.

Turker, D. (2008), "Measuring Corporate Social Responsibility: A Scale Development Study", Journal of Business Ethic, available at: http://www.springerlink.com/content/r755k13g7058282x/?p=5699abd523414d0a89 b07180d0d672c2\&pi=2

Vogel, D. (2005), The Market For Virtue: The Potential and Limits of Corporate Social Responsibility, Brookings Institution Press.

Waddock, S.A. and Graves, S.B. (1997), "The corporate social performance-financial performance link", Strategic Management Journal, Vol. 18, pp. 303-19.

Wartick, S.L. and Cochran, P.L. (1985), "The evolution of the corporate social performance model", Academy of Management Review, Vol. 10, pp. 758-69.

Wolfe, R. and Aupperle, K. (1991), "Introduction to Corporate Social Performance: Methods for Evaluating an Elusive Construct", in J. E. Post (ed.), Research in Corporate Social Performance and Policy, Vol. 12 (JAI Press, Greenwich, CT), pp. 265-268.

Wood, D.J. (1991), “Corporate social performance revisited”, Academy of Management Journal, Vol. 16, pp.691-718.

World Business Council for Sustainable Development (1999), “Corporate Social Responsibility. Meeting Changing Expectations", available at: http://www.wbcsd.org.

Ziegler, A., Schröder, M. and Rennings, K., (2007), “The effect of environmental and social performance on the stock performance of european corporations", Environmental and Resource Economics, Vol. 37, pp. 661-680. 